\title{
Identifikasi Hidangan pada Upacara Kesempatan Khusus Suku Tengger di Desa Argosari Kecamatan Senduro Kabupaten Lumajang
}

\author{
Tria Maryani*, Soenar Soekopitojo, Titi Mutiara Kiranawati \\ Universitas Negeri Malang, Jl. Semarang No. 5 Malang, Jawa Timur, Indonesia \\ *Penulis korespondensi, Surel: soenar.soekopitojo.ft@um.ac.id
}

Paper received: 11-03-2021; revised: 17-03-2021; accepted: 25-03-2021

\begin{abstract}
Tengger tribe has a dish that is served on special occasions ceremony. The special occasion ceremony held by the Tengger tribe is inseparable from the culture and Hindus's religion which is the majority religion of the Tengger tribe. Argosari Village is one of the villages that still carries out all special occasion's ceremonies related to custom and religion. This village is in Lumajang Regency. This research was using qualitative descriptive research, with data collection techniques used are interviews, observation, and documentation. The data source was obtained from interviews with five informants are the Dukun Pandhita of Argosari village, Mangku village, and society's Argosari. Data analysis is performed interactively with steps such as reduction, data presentation and drawing conclusions or verification and to check the validity of finding with member checking methode to Dukun Pandhita. The results of the research which is identifiying the special occasion dishes of Tengger tribe, there are 6 groupings dishes based on staple foods such as rice, side dishes such as omelette, fried chicken, fried noodles. Vegetable dishes include jangan benguk, jangan kentang. Snacks consist of pepes, pasung, jenang abang, apem, juadah, tetelan. The beverages such as tea and coffee. Dandananan such as gedhang ayu, pencok bakal.
\end{abstract}

Keywords: identification dishes; Tengger tribe; special occasion ceremony

\begin{abstract}
Abstrak
Masyarakat suku Tengger mempunyai hidangan yang disajikan pada upacara kesempatan khusus. Upacara kesempatan khusus yang dilaksanakan oleh masyarakat suku Tengger tidak terlepas dari kebudayaan dan agama Hindu yang merupakan agama mayoritas suku Tengger. Desa Argosari merupakan salah satu desa yang masih melaksanakan semua upacara kesempatan khusus yang berkaitan dengan adat maupun keagamaan, Desa ini terletak di Kabupaten Lumajang. Penelitian ini merupakan penelitian deskriptif kualitatif, dengan teknik pengumpulan data berupa wawancara, observasi dan dokumentasi. Sumber data diperoleh dari wawancara dengan lima informan yaitu Dukun Pandhita teraktif dengan langkah reduksi, penyajian data dan penarikan kesimpulan atau verifikasi. Pengecekan temuan dilaksanakan dengan member checking kepada Dukun Pandhita. Hasil dari penelitian ini adalah terdapat 6 pengelompokan hidangan yang disajikan pada kesempatan khusus, yaitu makanan pokok antara lain nasi, hidangan lauk pauk berupa telur dadar, ayam goreng. Hidangan sayuran antara lain jangan benguk, jangan kentang. Sedap-sedapan yang terbagi menjadi jajanan telesan berupa pepes, pasung, jenang abang, apem, juadah, tetelan dan jajanan garingan seperti matari dan onde-onde. Minuman antara lain teh dan kopi. Sesaji antara lain gedhang ayu, pencok bakal.
\end{abstract}

Kata kunci: identifikasi hidangan, suku Tengger, upacara kesempatan khusus

\section{Pendahuluan}

Indonesia merupakan salah satu negara dengan kepulauan yang secara demografis dan sosiologis adalah wujud dari sebuah bangsa yang Multikultural Kekayaan budaya yang 
diturunkan dari generasi ke generasi merupakan warisan nenek moyang yang dimiliki oleh negara Indonesia (Lusianti \& Rani, 2012).

Suku Tengger adalah salah satu suku yang memiliki toleransi beragama dan memiliki kepatuhan yang kuat untuk melaksanakan adat istiadat, baik itu adat yang berkaitan dengan sosial ataupun dengan agama yang dianut. Hal ini menyebabkan perubahan sosial yang terjadi pada masyarakat Tengger tidak terlalu signifikan. "Hal ini dikarenakan cara masyarakat untuk menjaga kelangsungan hidup mereka sendiri yaitu dengan cara mentaati dan melaksanakan norma dan nilai serta adat kebiasaan yang sudah dilakukan oleh nenek moyang mereka" (Purwasito, 2003). Masyarakat di desa Argosari sangat mematuhi adat-istiadat yang telah berlaku di Tengger sejak zaman nenek moyang mereka, hal dapat terlihat dari diadakan upacara adat baik itu yang berkaitan dengan keagamaan dan adat istiadat yang dilaksanakan hampir di setiap bulan di desa Argosari, ini merupakan salah satu cara mereka untuk menghormati nenek moyang mereka.

Setiap upacara yang dilakukan tidak terlepas dari hidangan yang disajikan, makanan itu sendiri memiliki peranan yang kuat dan sebagian besar merupakan bagian atau simbol dari upacara. Menurut penelitian tentang Kuliner Bali (dalam Ariani, 2017) Kuliner merupakan budaya yang yang mempelajari tentang pengadaan makanan dan minuman secara khas dimulai dari persiapan, pengolahan, penyajian dan penyimpanan makanan dan minuman tersebut.

Masyarakat suku Tengger memiliki hidangan untuk disajikan pada upacara kesempatan Khusus baik yang berkaitan dengan adat ataupun yang berkaitan dengan keagamaan, daur hidup ataupun sosial. Salah satu desa yang masih memiliki beragam kuliner suku Tengger adalah desa Argosari. Desa Argosari merupakan salah satu desa yang terdapat di Kabupaten Lumajang yang 99\% masyarakat yang menetap di desa ini adalah masyarakat suku Tengger. Hal ini dapat terjadi karena hampir seluruh warga di desa ini menikah dengan orang satu desa.

\section{Metode}

Penelitian ini menggunakan penelitian Deskriptif dengan pendekatan Kualitatif yang akan memiliki hasil akhir berupa paparan mengenai identifikasi hidangan pada upacara kesempatan khusus di desa Argosari Kecamatan Senduro Kabupaten Lumajang. Menurut Sugiyono (2016) seorang peneliti merupakan instrumen utama dalam penelitian kualitatif. Beragam sumber data yang diperoleh merupakan hasil dari mengumpulkan data dari berbagai sumber yaitu wawancara, observasi dan dokumentasi yang kemudian peneliti akan mereview semua data yang telah didapatkan (Creswell, 2010).

Penelitian ini dilaksanakan di Desa Argosari kecamatan Senduro Kabupaten Lumajang Jawa Timur, desa ini merupakan salah satu kawasan Taman Nasional Bromo Tengger Semeru (TNBTS) yang masyarakatnya merupakan suku asli Tengger yang masih menganut adat istiadat Tengger. Lokasi penelitian ini ditentukan dengan sengaja dikarenakan desa ini merupakan salah satu desa yang memiliki potensi wisata yang menjanjikan karena terdapat wisata alam yang sudah populer yaitu B-29 atau negeri di atas awan dan wisata budaya Tengger. 
Dalam penelitian ini sumber data sekunder yang digunakan adalah buku mengenai Suku Tengger, Agama Tradisional, Jurnal tentang suku Tengger, Jurnal yang membahas tentang upacara adat yang dilaksanakan di Suku Tengger dan Sumber data primer dalam penelitian ini didapatkan dengan cara wawancara langsung dengan beberapa tokoh antara lain: (1) Dukun Pandhita desa Argosari adalah tokoh yang memiliki pengaruh besar karena tugasnya dalam upacara dan pelaksanaan adat serta memimpin umat, selain itu dukun Pandhita merupakan tokoh yang mengetahui runtutan semua upacara, hidangan dan filosofi semua yang disajikan untuk keperluan upacara; (2) Pemangku desa untuk mendapatkan data tentang upacara keagamaan dimulai dari rangkaian prosesinya, hidangan dan sesaji yang dihidangkan pada setiap setiap upacara keagamaan, serta proses pembuatan dan penyajian semua kelengkapan dan hidangan untuk upacara keagamaan; (3) Masyarakat untuk memperoleh data tentang cara pengolahan dimulai dari pengadaan bahan sampai pembuatan hidangan dan penyajiannya.

Pengumpulan data primer dilakukan dengan teknik snowball sampling. Pengecekan keabsahan temuan dilaksanakan dengan member checking dengan wawancara secara langsung kepada dukun Pandhita yang merupakan kepala adat di desa Argosari. Analisis data yang dilaksanakan setelah pengumpulan data adalah mereduksi data, penyajian data dan verifikasi serta penarikan kesimpulan, analisis data dilaksanakan secara interaktif. Tahap penelitian yang dilaksanakan dalam penelitian ini antara lain tahap perencanaan, pelaksanaan, dan penulisan laporan.

\section{Hasil dan Pembahasan}

\subsection{Upacara Nyepi}

Hari raya Nyepi adalah hari raya tahun baru saka, hari raya ini dilaksanakan pada bulan Maret hampir setiap tahunnya menurut bulan masehi. Perayaan Nyepi di Suku Tengger tidak beda jauh dengan perayaan Nyepi di Bali ataupun di daerah lainnya di Indonesia, yang membedakaan perayaan Nyepi di Bali dan di desa Argosari adalah pada penggunaan daun janur yang biasanya digunakan di Bali tidak digunakan di perayaan Nyepi di desa Argosari ini, penggunaan janur diganti dengan daun pisang, karena di desa ini sulit untuk mendapatkan daun janur, hal ini dikarenakan letak geografis desa yang berada di ketinggian.

Ada beberapa rangkaian tradisi yang harus dilaksanakan antara lain :(1) Tawur Agung, (2) Arakan Ogoh-ogoh (3) Hari Raya Nyepi, (4) Upacara Ngembah Geni. Setelah upacara ngembah geni ada sebuah tradisi makan bersama (kenduren) yang dilaksanakan di Sanggar Agung, pada prosesi ini masyarakat akan membawa makanan yang berisi nasi putih, lauk pauk sesuai dengan kemampuan atau keinginan tiap individu, serta kue atau jajanan telesan atau keringan. Seluruh prosesi sebelum hari raya Nyepi dipimpin oleh Pemangku desa kecuali saat upacara Tawur Agung yang dipimpin oleh Dukun Pandhita. Seluruh dandanan yang akan disajikan pada upacara Nyepi akan dibuat disalah satu rumah warga yang telah ditentukan sebelumnya. seluruh proses pembuatan dandanan dan hidangan diawasi oleh Pemangku desa dan Dukun Pandhita.

\subsection{Upacara Galungan}

Galungan adalah salah satu upacara agama Hindu yang dilaksanakan setiap 210 hari atau 6 bulan sekali, perhitungan perayaan Galungan menggunakan pawukon atau wuku (1 wuku artinya 1 minggu, 1 bulan memiliki 30 hari) dan sesuai perhitungan Bali tidak 
berdasarkan kalender Tengger. Makna dari Galungan adalah kawodalan atau lahirnya kemenangan Darma melawan Adarma. Kelahiran dunia dan kelahiran manusia, Sebelum hari raya Galungan dilaksanakan ada beberapa tradisi yang biasanya dilakukan, antara lain: (1) Penampahan Galungan atau persiapan Galungan dilakukan satu hari sebelum upacara hari raya Galungan dimulai yaitu pagi rabu kliwon, dalam tradisi penamahan Galungan dilaksanakan beberapa prosesi yaitu: (a) Pendirian Penjor adalah salah satu hal yang wajib dibuat saat upacara Galungan berlangsung. Penjor adalah lambang kemakmuran, dan melambangkan rasa syukur kepada Tuhan; (b) Melinggihkan gedhang ayu dilaksanakan pada hari selasa malam yaitu tradisi mendirikan gedhang ayu yang berisi pisang raja, enjet, jambe, dan suruh ayu serta nasi 2 porsi, lauk-pauk 2 porsi, kue 2 porsi yang disajikan dalam piring dan minuman 2 gelas. Jumlah 2 porsi melambangkan laki-laki dan perempuan. Gedhang ayu yang dibuat diletakkan di atas meja dalam rumah dan selanjutnya didatangkan roh leluhur, diberi makan, diajak untuk mengikuti upacara galungan tersebut; (c) Pada saat penampahan galungan juga dilaksanakan pembuatan jajan untuk tradisi ater-ater atau ngasah, kue yang biasanya dibuat adalah apem, godoh (pisang goreng), pipis, cucur. Pada saat upacara Galungan, Dukun Pandhita tidak hanya membuat penjor, gedhang ayu kecil, dan kue-kue tetapi harus membuat banten pras, banten among, pencok bakal, dan jajanan seperti apem, pipis, godoh. (d) Ngasah atau aterater adalah salah satu tradisi saling mengantarkan makanan kepada tetangga atau saudara. Tradisi ini memiliki tujuan untuk mempererat tali persaudaraan. Ater-ater dilaksanakan malam hari sebelum hari sebelum hari raya Galungan dilaksanakan. Kue wajib dalam tradisi ini adalah apem yang melambangkan bumi itu bulat tidak ada awal dan akhir. Selain kue seperti juadah, pipis, juga disertakan nasi dan lauk pauknya. Untuk jumlah makanan yang diantarkan adalah tergantung pada "si pemberi" yang akan memberikan tidak ada syarat khusus.

(2) Hari raya Galungan mempunyai puncak acara yaitu sembahyang bersama yang dilaksanakan di Sanggar Agung sekitar pukul 07.00-12.00, setiap masyarakat menggunakan baju adat berupa jarik (untuk perempuan) dan beskap untuk baju adat (untuk laki-laki) serta udeng (ikat kepala untuk laki-laki). Pada saat hari raya Galungan, Dukun Pandhita tidak hanya membuat gedhang ayu tetapi membuat dandanan lainnya untuk di Sanggar Agung. Pada saat hari raya Galungan tidak harus melaksanakan kenduren seperti pada upacara lainnya, karena setelah sembahyang bersama dilaksanakan andon mangan atau berkunjung ke rumah tetangga atau saudara yang bertujuan untuk saling meminta maaf dan saling menyantap makanan yang telah disediakan oleh tuan rumah. Menu yang dihidangkan saat andon mangan tidak menentu, tergantung tuan rumah ingin menyajikan menu apa saja. (3) Penglebaran gedhang ayu (pelepasan gedhang ayu) dilakukan pukul 15.00 setelah sembahyang bersama di Sanggar Agung. Tradisi ini dilakukan di setiap rumah, penglebaran gedhang ayu mempunyai makna mengembalikan roh leluhur yang telah dilinggihkan (didatangkan) ketika penampahan galungan dilaksanakan. (4) Nyadran adalah mengunjungi pemakaman leluhur. Hal ini dilaksanakan satu hari setelah hari raya galungan. Nyadran dilaksanakan satu hari setelah hari raya galungan. Masyarakat Tengger melakukan tradisi ini karena dalam ajaran Tengger ada kepercayaan timbal balik 


\subsection{Upacara Kuningan}

Kuningan adalah upacara keagamaan yang masih satu rangkaian dengan Galungan. Makna dari Kuningan adalah kembalinya para leluhur ke kayangan setelah 10 hari dilinggihkan semenjak upacara galungan. Pada saat kuningan masyarakat hanya membuat gedang ayu kecil disertai dengan jenang abang dan jenang putih. Sebelum upacara kuningan dilaksanakan ada beberapa tradisi yang biasanya dilakukan oleh masyarakat desa Argosari.

Tradisi-tradisinya antara lain: (1) Penampahan kuningan atau persiapan kuningan yang dilakukan adalah pembuatan kupat dan lepet. Kupat dan lepet melambangkan laki-laki dan perempuan atau yoni dan lingga. Kupat dan lepet adalah makanan wajib saat kuningan di desa Argosari. Kegiatan penampahan kuningan dilaksanakan pada hari jumat Malam sabtu tepatnya satu hari sebelum upacara kuningan. Selain kupat dan lepet, makanan yang wajib ada saat perayaan kuningan adalah nasi kuning. (2) Ater-ater atau ngasah adalah tradisi bertukar makanan kepada tetangga atau saudara, tidak ada hidangan wajib dalam tradisi ater-ater. Tujuan dari ater-ater adalah mempererat tali persaudaraan. (3) Sembahyang bersama dilaksanakan pada hari sabtu di Pura Giri Semeru yang merupakan Pura terbesar di kabupaten Lumajang pada pukul 09.00. Pada sembahyang bersama tidak hanya dilaksanakan oleh masyarakat desa Argosari saja, tetapi oleh semua umat Hindu yang ada di Lumajang. Hal ini juga bertujuan untuk mempererat tali persaudaraan antara umat Hindu. Setelah melaksanakan sembahyang bersama, semua masyarakat melakukan tradisi kenduren atau makanan yang telah didoakan sebelum dimakan, dimana sebagian makanan dipersembahkan dan sebagian lainnya dimakan bersama. (d) Tradisi Penurunan penjor merupakan pertanda bahwa upacara galungan-kuningan telah berakhir. Penjor yang sudah diturunkan akan dibakar, penurunan penjor dilaksanakan pukul 15.00, sebelum penjor diturunkan harus dilaksanakan upacara penurunan yang dilaksanakan oleh setiap tuan rumah dengan sesaji gedhang ayu.

\subsection{Upacara Kasada}

Kasada adalah salah satu upacara adat yang dilaksanakan oleh semua masyarakat Tengger dari semua daerah. Kasada dilaksanakan pada bulan ke 12 pada perhitungan Tengger, Kasada dilakukan untuk memberikan persembahan kepada gunung Bromo yang dipercayai sebagai pemberi keselamatan dan kehidupan masyarakat Tengger, sehingga pelaksanaan upacara dilaksanakan dengan cara memberikan persembahan apa saja tetapi harus dengan hati yang ikhlas atau tulus. Masyarakat Tengger biasanya akan memberikan pengorbanan berupa hasil tandur tuwuh atau hasil bumi yang mereka tanam sendiri. Sebelum perayaan kasada terdapat beberapa tradisi yang harus dilaksanakan oleh masyarakat Tengger.

Tradisi-tradisi tersebut antara lain: (1) Sepeninga kasada dilaksanakna dengan cara bersembahyang di B29, karena disana terdapat petilasan Joko Niti yang merupakan salah satu leluhur masyarakat Tengger. Upacara ini dilaksanakan pada pukul 14.00 dan tujuan dari Sepeninga kasada adalah untuk membuka pintu gaib yang berada di B29. Setiap kawasan Tengger di semua daerah mempunyai gerbang sendiri-sendiri. Selain itu masyarakat setempat juga mempercayai bahwa tujuan lain dari bersembahyang di B29 adalah meminta izin atau pamit agar perjalanan ke Poten selamat dan tidak terjadi sesuatu apapun;(2) Pelaksanaan upacara kasada dilaksanakan pukul 02.00 dini hari. Bertempat di Poten atau padang pasir, sebelum berangkat ke Poten para dukun adat akan membuat ongkek di desanya masingmasing. Ongkek merupakan hasil bumi yang dihasilkan dari desa tersebut, serta bunga 
eidelwis yang melambangkan keabadian, bunga kenikir yang melambangkan kesucian serta plawah yang melambangkan kedamaian, apem, pipis, juadah, pasung serta pisang raja yang sudah masak yang melambangkan derajat tertinggi. Semua akan dirangkai menjadi satu berbentuk bulat melengkung yang melambangkan tidak ada awal dan tidak ada akhir. Ongkek dibuat sedemikian rupa agar mudah untuk dipikul, orang yang memikul ongkek adalah legen dan sesepuh.

Ongkek akan dipikul dari poten sampai ke kawah, apabila sebelum sampai ke kawah gunung Bromo, ongkek terjatuh seperti akibat dari terpeleset, maka itu berarti bahwa ongkek telah diterima di tempat terjatuhnya dan ongkek tidak dibawa sampai ke kawah gunung. Apabila dalam satu desa terdapat orang yang meninggal dalam waktu dekat sebelum perayaan kasada maka Dukun Pandhita tidak akan membawa ongkek.

Selain ongkek, dukun adat juga akan membawa banten rakan untuk dipersembahkan kepada dewa air, isi dari rakan sama seperti sesa gangga. Setelah selesai upacara banten rakan akan ditaruh di sumber air. Ada beberapa prosesi yang dilaksanakan pada saat upacara kasada di Poten antara lain: (a) Pembukaan kasada yaitu berupa pidato dan ada protokolnya. (b) Pembacaan sejarah kasada oleh Lurah Dukun atau dukun sepuh yaitu orang yang menjadi ketua dukun desa Tengger. (c) Puja Astuti yaitu prosesi menghaturkan banten pras ke gunung Bromo. (d) Pemilihan calon dukun, hal ini dilaksanakan apabila dukun di desa tersebut sudah tidak ada. Untuk menjadi dukun Pandhita ada beberapa syarat yang harus terpenuhi seperti harus hapal mantra. (e) Penyerahan ongkek biasa disebut dengan nglarung atau nglabuh kasada. (f) Penutupan upacara kasada. (g) Pujan kasada, yaitu upacara selametan yang dilakukan di desa masing-masing. Di desa Argosari pujan kasada dilaksanakan di rumah dukun pandhita, dimana semua masyarakat berkumpul dan melakukan selametan, masyarakat akan membawa beras untuk membuat perlengkapan upacara, yaitu banten pras, gedhang ayu, darsina, among, sesa gangga, sesa pertiwi.

\subsection{Upacara Karo}

Karo merupakan upacara adat yang dilaksanakan selama 15 hari, perhitungan perayaan karo berdasarkan sasih kalender Tengger, karo dilaksanakan pada bulan kedasa atau bulan ke10 pada kalender Tengger. Pada perayaan Karo tidak hanya dilakukan oleh umat Hindu suku Tengger tetapi oleh seluruh masyarakat Tengger di semua wilayah.

Pada jaman dahulu pelaksanaan Karo dirayakan di Balai desa, sedangkan sekarang Karo dilaksanakan di rumah kepala desa. Dalam upacara Karo terdapat beberapa prosesi yaitu: (1) Penentuan iuran merupakan langkah awal dari pelaksanaan Karo, dimana semua masyarakat satu desa berkumpul di suatu tempat untuk bermusyawarah mengenai biaya untuk Karo. Penentuan iuran akan disepakati oleh PHDI (Persatuan Hindu Dharma Indonesia), kepala desa, dan semua masyarakat desa Argosari. Penentuan iuran dilaksanakan satu bulan sebelum hari raya karo. (2) Mupu Karo adalah kegiatan mengumpulkan Sumbangan yang dikumpulkan berupa biji-bijian baik beras ataupun jagung ke masyarakat untuk digunakan saat karo berlangsung. Tidak ada jumlah mutlak berapa sumbangan yang harus diberikan. (3) Sepeninga karo dilaksanakan tujuh hari sebelum upacara karo, maka pada rangkaian upacara karo dilaksanakan tekani ping pitu dan muli e ping pitu. Sepeninga karo dipimpin oleh dukun pandhita, tujuan dari sepeninga karo adalah untuk memberitahu kepada roh leluhur bahwa akan diadakan upacara karo, 
(4) Tekani ping pitu adalah tradisi tujuh hari sebelum karo, dimana para masyarakat tidak boleh bepergian jauh, kecuali dengan tujuan untuk kembali sebelum pelaksanaan karo.

Pada tekani ping pitu masyarakat membuat gedang ayu sandingan yaitu gedang ayu yang berisi: (1) Pisang raja yang mempunyai makna untuk melinggihkan; (2) Pisang raja berjumlah 2 yang melambangkan siang dan malam; (3) Enjet, suruh ayu dan kapur ayu yang melambangkan bahwa manusia diciptakana, dipelihara dan dilebur; (4) Daun pisang melambangkan bahwa manusia tidak telanjang; (5) Baju laki-laki dan baju perempuan yang melambangkan leluhur yang telah mendahului; (6) Nasi, lauk pauk dan kue (pipis, pasung, tetel, juadah) untuk tamping. (5) Leliwet adalah tradisi memberikan persembahan kepada air dan pertiwi. Hal ini dimaksudkan memberikan rasa terimakasih kesemuanya, dan mengharapkan agar hubungan tetap seimbang. Leliwet dilaksanakan oleh setiap orang atau keluarga, dimana mereka menyuguhkan banten sesa gangga di sumber air dan banten sesa pertiwi di rumah serta ladang yang dimiliki. (6) Persembahyangan di Sanggar Agung. Persembahyangan dilaksanakan pagi hari pada hari raya karo oleh seluruh masyarakat Hindu Tengger yang berada di desa Argosari, setelah itu masyarakat melaksanakan kenduren. Pada saat karo masyarakat membawa anca (pisang dan kue yang dibentuk gunung serta nasi dan lauk pauknya). (7)

Tayuban adalah kesenian tradisional, yang dipertontonkan pada hari raya karo tepat pada sore harinya. Kesenian tayuban dipertontonkan dari jaman dahulu kala, kesenian itu bukan asli kesenian Tengger. Sebelum tayuban dipertontonkan tidak ada upacara khusus. Pada saat tayuban seluruh masyarakat berkumpul untuk menyaksikan. (8) Sesanti,Upacara ini merupakan salah satu tradisi yang dilaksanakan setelah hari raya Karo, sesanti dilakukan oleh tiap rumah yang ada di desa Argosari. Setiap rumah menyediakan: (1) 22 tumpeng kecil; (2) 22 takir; (3) 22 kue (jadah, pipis pasung); (4) 2 paket banten pras berisi 2 tumpeng; (4) 2 paket banten among berisi 1 tumpeng. (9) Ngobong petra/ puspa sarida adalah media tempat duduk atau (puspa yang berarti bunga dan sarida yang melambangkan manusia) bunga yang mewakili manusia. Petra berasal dari bunga edelweis, daun plapah dan senikir, andong merah atau klotok melambangkan kekuatan yang berasal dari dalam diri yaitu kulit, tulang, daging, setelah petra didoakan lalu di bakar. Ngobong petra dilaksanakan oleh Dukun Pandhita. Tempat pembakaran di Danyang/ Pasetran (belakang balai desa). (10) Nyadran adalah tradisi berkunjung ke makam para leluhur yang telah mendahului, nyadran sendiri mempunyai makna menunjukkan rasa syukur kepada pitara atau leluhur, karena tanpa mereka tidak akan ada kita, selain itu nyadran bermakna untuk mensucikan tanah yang sudah ditempati oleh leluhur yang telah mendahului.

\subsection{Hidangan Upacara Kesempatan Khusus}

Susunan hidangan di Indonesia terdiri dari makanan pokok, lauk pauk, sayur, sambal, sedap sedapan, dan minuman, Handayani \& Marwanti (2011). Dari keenam klasifikasi susunan menu hidangan lima diantaranya ditemukan di desa Argosari, selain itu terdapat hidangan yang disajikan tanpa proses pengolahan yaitu sesaji atau dandanan dan buah-buahan. Maka dari itu identifikasi hidangan pada kesempatan Khusus Suku 
Tengger Desa Argosari dikelompokan menjadi tujuh yaitu: makanan pokok, lauk pauk, sayur, sedap sedapan, minuman, sesaji atau dandanan dan buah-buahan.

Hidangan yang disajikan pada kesempatan khusus akan hidangkan pada proesi tertentu seperti Ater-ater, Kenduren, dan tekani ping pitu. Pada prosesi ater-ater seluruh masyarakat membuat kue yang selanjutnya kue dan hidangan lainnya akan ditukarkan dengan tetangga dekat atau kerabat, kue yang biasa disajikan adalah apem, juadah, pepes. Kue atau jajanan melambangkan kemandirian. Pada posesi kenduren di berbagai upacara, seluruh masyarakat akan membawa nasi, lauk pauk dan kue yang akan dimakan bersama setelah upacara atau sembahyang selesai dilaksanakan. Nasi merupakan lambang dari kesucian karena memiliki warna putih. Proses pembuatan nasi dengan cara "dikaru", dimana beras dimasukan ke dalam dandang sampai setengah matang lalu ditambah air panas kemudian dimasak kembali sampai matang. Lauk pauk yang disajikan sesuai dengan selera masyarakat. Pada prosesi tekani ping pitu seluruh rumah akan menyajikan hidangan untuk tamu yang berkunjung selama tujuh hari. Menu yang dibuat disesuaikan dengan kemampuan dan selera tuan ruan rumah. Komposisi hidangan yang disajikan antara lain nasi putih, lauk pauk, minuman, jajanan telesan dan garingan serta buah yang sering dihidangkan adalah pisang karena pisang merupakan buah yang sering disajikan dan memiliki filosofi dalam penyajiannya.

\subsection{Hidangan Khusus atau Dandanan}

Masyarakat desa Argosari memiliki kepercayaan bahwa sebagai manusia harus berterimakasih baik itu kepada Sang Hyang Widhi yang telah menciptakan alam yang telah memberikan kehidupan dan leluhur yang telah mendahului. Oleh karena itu seluruh kegiatan masyarakat desa Argosari tidak terlepas dari sesaji baik itu banten ataupun tamping yang merupakan simbol dari rasa terimakasih yang masyarakat desa Argosari berikan. Hal ini sesuai dengan pernyataan (Endraswara, 2003), Pada pelaksanaan upacara adat dibutuhkan ubo rampen atau sesaji. Sesaji merupakan aktualisasi dari pikiran, keinginan, dan perasaan pelaku untuk lebih mendekatkan diri kepada Tuhan. Sesaji juga merupakan wacana simbol yang digunakan sebagai sarana untuk negosiasi spiritual kepada hal-hal gaib. Hal ini dilakukan agar makhluk-makhluk halus di atas kekuatan manusia tidak mengganggu. Dengan pemberian makan secara simbolik kepada roh halus, diharapkan roh tersebut akan jinak, dan mau membantu hidup manusia. Hal ini sesuai dengan pernyataan Pak Sukarto selaku Mangku desa, bahwa tamping diletakan di setiap sudut rumah atau di setiap pintu agar roh halus tidak mengganggu.

Sesaji atau dandanan yang dihidangkan oleh masyarakat desa argosari tidak harus mewah tetapi harus lengkap hal ini disebut dengan istilah jajangkepan. Setiap sesaji atau dandanan yang disajikan memiliki tujuan tersendiri. Tidak semua sesaji di desa Argosari dipersembahkan dalam keadaan mentah, tetapi terdapat beberapa sesaji atau dandanan yang melalui proses pengolahan seperti ingkung dan jajanan telesan. Dandanan yang selalu disajikan pada setiap upacara kesempatan khusus adalah Gedhang ayu mempunyai makna untuk melinggihkan para leluhur, untuk menyajikan gedhang ayu di taruh di piring tetapi khusus untuk upacara galungan, gedhang ayu disajikan dalam ember. 
Banten among mempunyai tujuan untuk berterimakasih kepada semesta karena telah mengemong (mengasuh) dan berharap kedepannya agar lebih baik. Hal ini sesuai dengan hasil wawancara Pak Sukarto selaku mangku desa di desa Argosari yang menyatakan, "Banten among pasti menggunakan satu tumpeng berbentuk setengah lingkaran, yang melambangkan perempuan atau seorang ibu". Banten among selalu disajikan dengan Banten pras adalah banten yang berisi tumpeng pras yaitu tumpeng yang berbentuk kerucut, bentuk dari tumpeng pras melambangkan gunung. Isi banten pras adalah pisang, suruh, kinangan, bera, daun pisang, kue. Banten pras selalu disajikan dengan 2 tumpeng kerucut sedangkan banten among hanya disajikan 1 buah tumpeng.

Pencok bakal adalah dandanan yang berisi tumpeng 5 buah, telur ayam kampung, bumbu pẽpẽk, sabun dan kaca. Lima merupakan lambang dari arah mata angin. Telur ayam kampung melambangkan dunia beserta isinya. Jenang disajikan dalam lima warna yang memiliki makna berbeda-beda, jenang putih terbuat dari beras yang melambangkan arah timur, Jenang merah terbuat dari beras merah yang melambangkan selatan, jenang barat berwarna kuning terbuat dari beras jagung yang melambangkan barat, jenang hitam yang terbuat dari beras hitam yang melambangkna utara dan jenang pancawarna yaitu jenang yang terbuat dari kacang hijau yang melambangkan tengah. Serta pencok kacang atau Bumbu pẽpẽk yang melambangkan pait getirnya hidup.

Sesa gangga atau kubahan adalah dandanan yang dipersembahkan untuk dewa air atau dewa gangga, sesa gangga dipersembahkan di setiap sumber air yang dimiliki. Sesa gangga terdiri dari bunga edelwis, plawah, senikir. Bunga edelweis melambangkan keabadian, senikir melambangkan ketulusan hati dan daun plawah melambangkan kedamaian yang berasal dari ketulusan Setiap upacara pasti ada banten air.

Caru merupakan banten yang dibuat dengan tujuan memberi makan buta kala, banten caru terdiri dari (1) tumpeng pancawarna yaitu tumpeng yang terbuat dari lima bahan disatukan dan dibentuk menjadi tumpeng untuk makanan dipersembahkan kepada buta kala, jumlah tumpeng ada dua yang melambangkan siang dan malam; (2) jenang abang dan jenang putih melambangkan kan perempuan dan laki-laki; (3) jenang sangkala mempunyai makna membersihkan kala; (4) jenang kuning melambangkan keheningan; (5) sate; (6) dawet; (7) kelapa gading; (8) polo pendem; (9) serabi biru. Caru pangrua merupakan banten yang bermakna untuk menetralisir hal negatif di alam semesta. Caru pangrua terdiri dari (1) Tumpeng besar yang dihidangkan terbalik; (2) pisang muda 5 sisir; (3) kelapa gading 1 buah, (3) mie sebagai pengganti bera atau hasil tanah.

Ongkek merupakan sesaji yang dipersembahkan khusus pada upacara kasada. Ongkek adalah hasil bumi, kue-kue serta pisang yang dirangkai sedemikian rupa sehingga berbentuk bulat dan mudah untuk dIpikul. Pada perayaan kasada, ongkek akan dipikul ke Poten untuk akhirnya dilarung di gunung bromo sebagai persembahan.

Selain sesaji yang dihidangkan terdapat juga hidangan yang disajikan untuk kelengkapan upacara antara lain nasi putih selain dihidangkan dengan tujuan untuk dikonsumsi, terdapat tujuan lain dari dihidangkannya nasi putih yaitu sebagai tamping (makanan yang dimakan oleh masyarakat dalam setiap rumah yang disisihkan sedikitsedikit untuk makan para penjaga sebelum akhirnya manusia makan. Lauk pauk 
mempunyai filososfi seperti upah untuk orang yang bekerja, tidak ada filosofi per bahan, jadi semua lauk merupakan lambang pengorbanan. Semua hewan boleh dijadikan lauk kecuali tikus karena tidak pantas. Cara pengolahan sendiri terganung kinginan yang memasak.

Sedap-sedapan atau jajanan telesan/gagaringan adalah kue yang dibuat untuk dihidangkan dalam upacara ataupun untuk disajikan dengan tujuan untuk dikonsumsi, Pada pembuatan kue pertama ditujukan untuk sesaji dan untuk \proses pembuatan selanjutkan kue boleh dimakan oleh manusia. Hal ini dikarenakan kue yang pertama kali dibuat masih suci. Makanan khas yang asli sini juadah pẽpẽs pasung. pẽpẽs itu nogo sari. Juadah semacam tetel. Pasung semacam kaya apem tapi dibikinkan contong, Juadah adalah lambang kemandirian karena dibikin sendiri tidak boleh beli atau lambang kemantapan. Ketiganya mempunyai filosofi atau lambang yang sama yaitu kemandirian, untuk jumlah yang disajikan, menyesuaikan baik itu untuk dikonsumsi ataupun kelengkapan dandanan.

\section{Simpulan}

Hidangan pada kesempatan khusus di desa Argosari memiliki 2 jenis yaitu hidangan yang disajikan untuk untuk dikonsumsi dan hidangan yang disajikan untuk kelengkapan upacara atau yang biasa disebut dengan dandanan atau banten. Setiap sesaji atau dandanan yang disajikan dalam setiap upacara memiliki tujuan yang berbeda walaupun jenis dandanan yang disajikan sama, seperti gedhang ayu yang disajikan dalam setiap upacara memiliki tujuan yang berbeda: (1) gedhang ayu kecil dan daksina dipersembahkan pada upacara Nyepi; (2) Pada upacara Galungan dipersembahkan gedhang ayu kecil, karena pada upacara Galungan gedhang ayu merupakan tempat linggih leluhur keluarga, (3) Pada upacara Kuningan gedhang ayu kecil yang disajikan karena upacara Kuningan adalah upacara yang satu rangkaian dengan upacara Galungan maka dari itu tujuan disajikannya gedhgang ayu sama seperti pada upacara Galungan. (4) pada upacara Kasada, Gedhang ayu kecil dan gedhang ayu daksina disajikan pada saat Pujan Kasada; (5) Pada Upacara Karo disajikan Gedhang ayu Sandingan.

Hidangan yang selalu ada yaitu jenang abang dan jenang putih. Selain itu selalu disediakan hidangan berupa nasi putih, lauk pauk dan sedap-sedapan yang dihidangkan untuk leluhur dan penunggu dalam istilah masyarakat Tengger dikenal sebagai tamping, tamping diletakan di setiap pintu dan diganti setiap tuan rumah akan melaksanakan makan, selain itu terdapat sesaji yang biasanya disajikan pada upacara khusus baik itu upacara keagamaan ataupun adat antara lain: banten pras, banten among, pencok bakal. Dan ada beberapa sesaji atau dandanan yang khusus disajikan untuk upacara tertentu seperti caru pangrua. Jajanan telesan merupakan kue yang hampir selalu ada dalam setiap upacara baik itu untuk dikonsumsi ataupun untuk persembahan, jajanan telesan antara klain apem, pasung, pepes, tetelan, juadah. Semua sedap-sedapan yang dibuat untuk kelengkapan upacara memiliki filosofi kemandirian. Nasi putih yang disajikan pada setiap upacara memiliki filosofi kesucian, dan semua lauk pauk yang disajikan memiliki filosofi pengorbanan atau upah hasil sebuah usaha.

Bahan yang digunakan untuk membuat dandanan ataupun makanan yang disajikan adalah bahan yang didapat dari alam sekitar, dan beberapa bahan yang harus tersedia untuk kelengkapan upacara tetapi tidak tersedia di alam sekitar maka masyarakat akan membeli ke Senduro. Karena di desa Argosari mengenal istilah jajangkepan yaitu suatu dandanan tidak harus mewah atau banyak tetapi harus lengkap. 
Alat yang digunakan pada persiapan hidangan ini dapat dibagi menjadi tiga, yaitu alat persiapan, pengolahan, dan penyajian. Alat penyajian yang diguanakan untuk sesaji ataupun untuk hidangan antara lain daun pisang, piring, tampah. Pemilihan alat hidang tidak memiliki makna tertentu, kecuali pada penyajian beberapa jajanan telesan yang menggunakan daun pisang yang memiliki makna bahwa manusia tidak telanjang.

Setiap hidangan yang disajikan untuk kesempatan khusus memiliki filosofi sesuai dengan tujuan dilaksanakannya upacara, hidangan yang disajikan memiliki filosofi dalam keseluruhan, warna atau bentuk dari hidangan yang disajikan. Filosofi dari kelengkapan upacara kesempatan khusus antara lain: (1) nasi putih memiliki warna putih yang memiliki filosofi kesucian;(2) semua lauk pauk yang disajikan untuk upacara kesempatan khusus memiliki makna pengorbanan atau upah dari sebuah usaha;(3) jajanan yang disajikan memiliki filosofi kemandirian, dan beberapa jajanan telesan memiliki makna tertentu seperti apem memiliki bentuk bulat yang melambangkan bumi dan tidak awal dan tidak ada akhir, pẽpẽs yang berbentuk persegi empat yang melambangkan arah mata angin dan dibungkus dengan daun pisang yang memiliki makna bahwa manusia tidak telanjang, begitu juga dengan juadah yang dialasi dengan daun pisang memiliki filosofi yang sama.

Selain itu setiap sesaji yang dihidangkan untuk kelengkapan upacara memiliki filosofi sesuai dengan tujuan upacara antara lain: (1) banten pras, Inti dari pras adalah sebagai pembersih, banten pras memiliki isi pisang, suruh, enjet, gambir, bera, ketan, ingkung, alasnya daun pisang, jajan tetelesan (pipis, pasung, juadah, tetel) dan jajan gagaringan (rengginang dan matari); (2) Banten among pasti menggunakan satu tumpeng berbentuk setengah lingkaran, yang melambangkan perempuan atau seorang ibu; (3) Pencok bakal adalah dandanan yang berisi tumpeng 5 buah, telur ayam kampung, bumbu pẽpẽk, sabun dan kaca. Lima merupakan lambang dari arah mata angin. Telur ayam kampung melambangkan dunia beserta isinya. Jenang disajikan dalam lima warna yang memiliki makna berbeda-beda, jenang putih terbuat dari beras yang melambangkan arah timur, Jenang merah terbuat dari beras merah yang melambangkan selatan, jenang barat berwarna kuning terbuat dari beras jagung yang melambangkan barat, jenang hitam yang terbuat dari beras hitam yang melambangkna utara dan jenang pancawarna yaitu jenang yang terbuat dari kacang hijau yang melambangkan tengah; (4) Sesa gangga terdiri dari bunga edelwis, plawah, senikir. Bunga edelweis melambangkan keabadian, senikir melambangkan ketulusan hati dan daun plawah melambangkan kedamaian yang berasal dari ketulusan; (5) Caru merupakan banten yang dibuat dengan tujuan memberi makan buta kala; (6) Caru pangrua merupakan banten yang bermakna untuk menetralisir hal negatif di alam semesta; (7) Ongkek merupakan sesaji yang dipersembahkan khusus pada upacara kasada, bentuk ongkek biasanya bulat yang melambangkan tidak awal dan tidak ada akhir atau berputar.

Beberapa hidangan pada kesempatan khusus memiliki warna yang sarat akan makna seperti warna putih pada juadah dan tetelan yang melambangkan kesucian, serta pemilihan nasi putih untuk dihidangkan dalam beberapa tradisi karena warnanya yang putih yang memiliki makna kesucian. Warna kuning yang memiliki senikir melambangkan ketulusan hati dan kuning pada jenang melambangkan barat, warna merah pada bunga plawah melambangkan pengorbanan dan warna merah pada jenang abang melambangkan selatan. Warna hitam pada pencok bakal melambangkan utara, dan perpaduan kelima warna melambangkan tengah. 
Bentuk pada hidangan yang dipersembahkan dalam kesempatan khusus memiliki makna tersendiri. Beberapa hidangan yang bentuknya memiliki makna antara lain: (1) Lingkaran dan setengah lingkaran, Hidangan yang memiliki bentuk lingkaran antara lain apem, ongkek, ancah bentuk lingkaran melambangkan alam semesta, dan tidak awal tidak ada akhir. Dan hidangan yang memiliki bentuk setengah lingkaran adalah tumpeng among yang memiliki melambangkan seorang ibu. Hal ini sesuai dengan hasil wawancara dengan Pak Karyoleh selaku dukun Pandhita di desa Argosari. (2)Persegi panjang, Hidangan yang memiliki bentuk persegi panjang antara lain juadah. Berdasarkan hasil observasi dan wawancara dengan Pak Karyoleh selaku dukun Pandhita desa Argosari menyatakan bentuk persegi panjang juadah melambangkan empat arah mata angin (barat, timur, selatan, utara). (3) Segitiga, Hidangan yang memiliki bentuk segitiga antara lain tumpeng pras, tumpeng panca warna dan tumpeng caru pangrua. Berdasarkan hasil observasi dan wawancara dengan Pak Karyoleh selaku Mangku desa menyatakan bentuk segitiga merupakan lambang gunung atau laki-laki. (4) Posisi ingkung, Ayam ingkung saat dibakar dibentuk menunduk yang melambangkan keheningan, selain itu menunduk merupakan posisi tunduk kepada Sang Hyang Widi. Hal ini berdasarkan hasil wawancara dengan Pak Sukaro selaku mangku desa Argosari.

Di desa argosari penyajian hidangan untuk kesempatan khusus berbeda-beda tergantung makanan apa yang akan dihidangkan. Hal ini juga berlaku untuk sesaji yang dihidangkan. Untuk nasi putih bersama lauk-pauk serta jajanan akan dihidangkan dalam piring jika dalam tradisi ater-ater, anjangsana, kenduren. Untuk tamping atau sesaji yang dipersembahkan untuk roh yang menunggu dirumah ataupun di setiap tempat (sumber air, perempatan) akan digunakan daun pisang sebagai alas. Untuk sesaji masyarakat desa argosari akan menggunakan takir untuk penyajian sesaji, seperti untuk jenang abang dan jenang putih yang dipersembahkan untuk upacara nyepi. Selain itu daun pisang digunakan untuk alas jajanan telesan yaitu juadah dan dibungkus dengan daun pisang seperti pepes. Daun pisang menyimbolkan bahwa manusia tidak telanjang. Hal ini dipaparkan oleh Pak Karyoleh selaku Dukun Pandita desa Argosari.

\section{Daftar Rujukan}

Lusianti, L.P. \& Rani, F. 2012. Model Diplomasi Indonesia Terhadap UNESCO Dalam Mematenkan Batik Sebagai Warisan Budaya Indonesia Tahun 2009. Jurnal Transnasional, 3(2), 1. Dari https://ejournal.unri.ac.id/index.php/JTS/article/view/72/66.

Sutarto, A. 2006. Sekilas Tentang Masyarakat Tengger. (Online) http://repositori.kemdikbud.go.id/1106/1/Masyarakat_Tengger.pdf, diakses 4 April 2019.

Purwasito, A. 2003. Agama Tradisional. Yogyakarta: Penerbit Lkis Yogyakarta

Creswell, J. W. 2010. Research Desain. Terjemahan Achmad Fawaid. Yogyakarta: Pustaka Pelajar.

Sugiyono. 2016. Metode Penelitian Kuantitatif, Kualitatif dan R\&D. Bandung: Penerbit Alfabeta.

Handayani, T. H. W.\& Marwanti. 2011. Pengolahan Makanan Indonesia, (Online), (https://www.scribd.com/doc/242503003/Modul-Ppg-Pengolahan-Makanan-Indonesia), diakses 3 April 2019.

Ariani, R. P. 2017. Mengenal Kuliner Bali. Depok: PT. Raja Grafindo Persada. 